\title{
Penetrating eye injuries from writing instruments
}

This article was published in the following Dove Press journal:

Clinical Ophthalmology

29 December 2011

Number of times this article has been viewed

\section{Simon P Kelly Graham MB Reeves \\ The Royal Bolton Hospital, Bolton, UK}

Correspondence: Simon P Kelly Ophthalmic Department, Royal Bolton Hospital, Minerva Road, Bolton BL4 OJR, UK

Tel +44 I204390694
Purpose: To consider the potential for ocular injury from writing implements by presenting four such cases, and to consider the incidence of such eye injuries from analysis of a national trauma database.

Methods: The Home and Leisure Accident Surveillance System was searched for records of eye injuries from writing instruments to provide UK estimates of such injuries. Four patients with ocular penetrating injury from pens or pencils (especially when caused by children), and examined by the authors, are described which illustrate mechanisms of injury.

Results: It is estimated that around 748 ocular pen injuries and 892 ocular pencil injuries of undetermined severity occurred annually in the UK during the database surveillance period 2000-2002. No eye injuries from swords, including toy swords and fencing foils, were reported.

Conclusion: Ocular perforation sometimes occur from writing instruments that are thrown in the community, especially by children. Implications for policy and prevention are discussed. Non-specialists should have a low threshold for referring patients with eye injuries if suspicious of ocular penetration, even where caused by everyday objects, such as writing instruments.

Keywords: eye injury, eye, children, mechanism, writing instruments, prevention

\section{Introduction}

We propose that the longstanding adage "the pen is mightier than the sword" still rings true, both in general life and specifically in relation to risk of ocular injury from pens, pencils, or swords. Penetrating eye injury is estimated to have a population incidence of about 1 in 29,000. ${ }^{1}$ The incidence of eye injury from writing instruments such as pens or pencils is uncertain. Four patients who were victims of penetrating eye injuries from writing instruments thrown by children are reported. Three of these patients presented to the authors' emergency department (Cases 1-3) and required urgent ophthalmic surgery. Case 4 came to the author's attention for medico-legal reasons from a nearby area. Surgical repair was undertaken within 24 hours of injury in all cases.

\section{Material and methods Case reports Case I}

A 14-year-old female was attending school when a fellow student threw a ballpoint pen from a range of 2 meters in the classroom. Vision was 6/60 on presentation. A full thickness $5 \mathrm{~mm}$ corneal laceration with iris dialysis required surgical repair. Localized lens opacification developed. Vision is currently 6/12 Snellen. 


\section{Case 2}

A 33-year-old female was hit by a ballpoint pen in her home. The pen was thrown to her to "catch" by her two year old son while tidying up. She sustained $3 \mathrm{~mm}$ full thickness corneal laceration with iris prolapse requiring repair. A pleasing post-operative anatomical outcome was achieved. Vision recovered from $6 / 24$ on presentation to $6 / 6$ unaided following surgical repair.

\section{Case 3}

A 29-year-old male was injured by a fountain pen thrown by his infant stepson from a distance of 2-3 meters in a domestic accident. A $4 \mathrm{~mm}$ full thickness corneal laceration with iris prolapse required urgent repair. Vision was $6 / 24$ on presentation and was $6 / 6$ within 2 post-operative months with correction of induced astigmatism.

\section{Case 4}

A 10-year-old male was attending school when a fellow student threw a pencil from a range of 1-2 meters in the classroom. A full thickness corneal laceration and traumatic lens injury was sustained. Vision was less than $6 / 60$ on presentation. Surgical removal of traumatic cataract was required with insertion of an intraocular lens implant. Following surgery $6 / 6$ vision was achieved with optical correction of the induced astigmatism from the corneal trauma (Figure 1).

\section{Epidemiological analysis}

The Home and Leisure Accident Surveillance System (HASS/LASS) is a record of home and leisure accidents that caused injuries serious enough to warrant a visit to participating hospitals in the UK but excluding fatal injuries. ${ }^{2}$ Sixteen to 18 UK-wide departments of emergency medicine

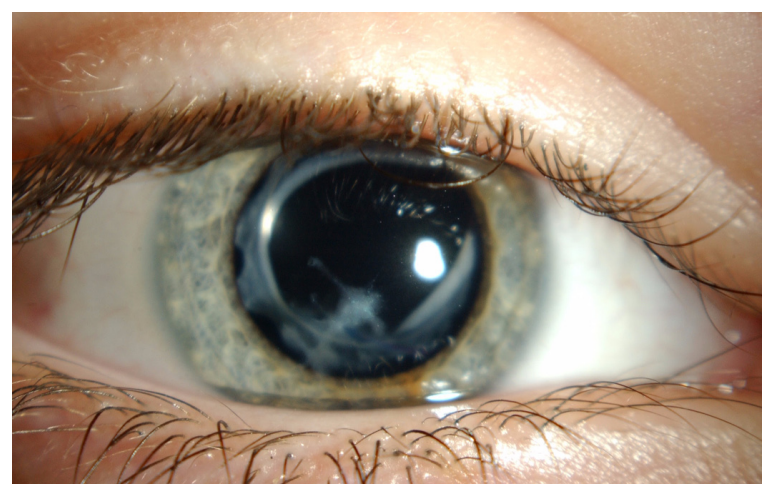

Figure I Case 4. Corneal scar following pencil injury. An intraocular lens is in situ. participated in the HASS/LASS injury surveillance scheme. Data collection ceased in 2003. This resource has since been maintained by the Royal Society for Prevention of Accidents (RoSPA). At our request RoSPA officers searched these databases for records of eye injuries. Records of eye injuries were examined. Eye injuries sustained from writing instruments or swords were considered.

\section{Results}

The HASS/LASS database search for cases of victims of accidents recorded as "eye injuries" returned 27,471 sample victims of accidents for 2000-2002 (ie, those that needed attendance and/or treatment at the participating hospitals). 121 records of eye injury associated with pens and 146 of such associated with pencils were located as recorded by participating hospitals in the HASS/LASS scheme throughout 2000-2002 (Table 1). These records describe a range of injuries but do not contain detailed clinical findings or any patient outcomes. Accuracy of reported data in HASS/LASS cannot be tabulated against clinical records.

A limitation of our study is that HASS/LASS data excludes fatal injuries and injuries sustained at work. Furthermore, injuries not requiring attendance at the participating hospital Emergency Departments are not included. The UK national estimate was calculated by using the HASS/ LASS sample injury cases and national multipliers (provided in brackets, by year), as is the method then specified by the Department of Trade and Industry for 2000 (17.74), 2001 (17.85), and 2002 (20.50) respectively. ${ }^{2}$ Extrapolating these figures results in estimates of 2244 ocular pen injuries (on average 748 per annum) and 2676 ocular pencil injuries throughout the 3 year surveillance period of 2000-2002 (on average 892 per annum) in the UK. In contrast, no eye injuries from swords, including toy wooden swords or fencing foils, were found on the database throughout this time period.

\section{Discussion}

The four local patients described demonstrate the potent hazards posed by writing instruments when used as missiles, by either accident or intent, especially by children. The HASS/ LASS data suggests that such environmental injury mechanism was relevant nationally in the UK in 2000-2002. We are not aware of any resources that would allow more recent data on such eye injuries in the UK to be data mined.

Published studies of penetrating eye injuries from the UK record sporadic cases caused by writing instruments. ${ }^{3-5}$ An analysis of risk factors amongst 115 patients requiring 
Table I Eye injuries from pen and pencil recorded on HASS/LASS database 2000-2002 from participating hospitals and resultant UK estimates*

\begin{tabular}{|c|c|c|c|c|c|}
\hline \multirow[t]{2}{*}{ Year } & \multicolumn{2}{|c|}{ Returns from the sample hospitals } & \multirow{2}{*}{$\begin{array}{l}\text { UK estimates* } \\
\text { ocular pen injuries }\end{array}$} & \multirow{2}{*}{$\begin{array}{l}\text { Ocular pencil injuries } \\
\text { (returns from the } \\
\text { sample hospitals) }\end{array}$} & \multirow{2}{*}{$\begin{array}{l}\text { UK estimates* } \\
\text { ocular pencil injuries }\end{array}$} \\
\hline & $\begin{array}{l}\text { Ocular injuries } \\
\text { (all causes) }\end{array}$ & $\begin{array}{l}\text { Ocular } \\
\text { pen } \\
\text { injuries }\end{array}$ & & & \\
\hline 2000 & 9465 & 53 & 940 & 62 & 1099 \\
\hline 2001 & 9257 & 34 & 607 & 55 & 982 \\
\hline 2002 & 8749 & 34 & 697 & 29 & 595 \\
\hline
\end{tabular}

Note: *The UK national estimate was calculated by using the HASS/LASS sample injury reports and National Multipliers (provided in brackets, by year), as is the method then specified by the Department of Trade and Industry for 2000 (I7.74), 200 I (I7.85), and 2002 (20.50) respectively. ${ }^{2}$

surgery in Manchester for ocular perforation throughout 1998-2004 revealed that injury from sharp/projectile mechanisms had a $20 \%$ risk of resulting in severe visual loss or removal of the eye. ${ }^{3}$ Of relevance, four cases of pencil injuries causing ocular perforation were observed in that case series. Two cases of ocular penetrations from pens required surgery in Birmingham between January 2000 and June 2004 as a result of eye injuries sustained in the home. ${ }^{4}$ Two cases of eye injuries from pencils were reported in the Scottish ocular trauma survey. ${ }^{5}$ The Writing Instrument Manufacturers Association (USA) indicated they were unaware of measures to improve the ocular safety of writing instruments, save the use of less toxic inks (unpublished data). The European Writing Instrument Manufacturers Association are aware of the need to comply with relevant European Toy Safety standards but point out that pencils and other writing instruments are considered a special case in the legislation by the fact that the point is required to be exposed to perform its intended function (unpublished data).

Guarding against eye injuries caused by assault or accident is problematic as there are a wide variety of everyday objects that are potential sight-threatening weapons or hazards. Of relevance, eye injury is the most important causal factor of unilateral blindness worldwide. ${ }^{6}$ Importantly, 1 in 6 of ocular perforation injury in children occurs when an object is thrown. ${ }^{7}$ Preventative measures have been important in reducing motoring and workplace related eye injuries. ${ }^{8}$ Fireworks and darts are also well recognized as hazards for ocular injury in the UK and for which eye injury prevention measures have been suggested. ${ }^{9,10}$ In common with darts, writing instruments have a pointed end causing the kinetic energy to be concentrated in a very small area. This increases the chance of ocular penetration, particularly on impact with the cornea as in cases described by the authors. It was suggested during the peer review of this manuscript that a warning be put on pen and pencils, indicating that these items could be dangerous for the eye. Such advocacy in Europe would require parliamentary action at European Union level. The authors intend to raise this matter via parliamentary channels as has been undertaken with calls that warnings of the ocular hazards of smoking appear on tobacco products. ${ }^{11}$

Diagnosing penetrating eye injuries is not always straightforward. Specialist examination by an ophthalmologist is advised. Delay or missed diagnosis of penetration sometimes occurs and is associated with less favorable visual outcomes.

\section{Conclusion}

While it is impossible to protect the public against all risks of eye injury, including injury from thrown everyday objects, it may be worthwhile highlighting that seemingly innocuous objects such as pens/pencils can and do cause severe eye injury. Importantly, all victims of penetrating eye injury presented herein were associated with children or teenagers throwing writing instruments at family members or classmates for whatever reasons. Thus, educating teachers, parents, and children about the risk of throwing writing instruments in the home or in schools may be a worthwhile public health goal. Eye injury from writing instruments in schools may pose liability risks to educational providers. The authors are aware of such legal claims against schools in two of the cases presented. Non-specialists should have a low threshold for referring patients with eye injuries if suspicious of ocular penetration, even where caused by everyday objects, such as writing instruments. We conclude that in regard to our eyes, pens continue to look and behave mightier than do swords.

\section{Acknowledgments}

We are extremely grateful to the Royal Society for the Prevention of Accidents for data extraction from the Home Accident and Leisure Accident Surveillance Systems. 


\section{Disclosure}

Patient consent for publication was obtained in all cases mentioned. SPK and GMBR are responsible for drafting this manuscript. SPK undertook the emergency ophthalmic surgical treatment in two of the patients reported upon herein.

\section{References}

1. Landen D, Baker D, LaPorte R, Thoft RA. Perforating eye injury in Allegheny County, Pennsylvania. Am J Public Health. 1990;80(9): $1120-1122$.

2. Department of Trade and Industry. 24th (final) Report of the Home and Leisure Accident Surveillance System. 2000, 2001 and 2002 data. Department of Trade and Industry. 2003. London. Available from: http://www.hassandlass.org.uk/query/reports/2000_2002.pdf. Accessed December 6, 2011.

3. Rahman I, Maino A, Devadason D, Leatherbarrow B. Open globe injuries: factors predictive of poor outcome. Eye (Lond). 2006;20(12): $1336-1341$
4. Bhogal G, Tomlins PG, Murray PI. Penetrating ocular injuries in the home. J Public Health. 2007;29(1):72-74.

5. Desai P, MacEwen CJ, Baines P, Minassian DC. Epidemiology and implications of ocular trauma admitted to hospital in Scotland. J Epidemiol Community Health. 1996;50(4):436-441.

6. Negrel AD, Thylefors B. The global impact of eye injuries. Ophthalmic Epidemiol. 1998;5(3):143-169.

7. Thompson CG, Kumar N, Billson FA, Martin F. The aetiology of perforating ocular injuries in children. Br J Ophthalmol. 2002;86(8): 920-922.

8. McGwin G Jr, Hall TA, Xie A, Owsley C. Trends in eye injury in the United States, 1992-2001. Invest Ophthalmol Vis Sci. 2006;47(2): 521-527.

9. Knox FA, Chan WC, Jackson AJ, Foot B, Sharkey JA, McGinnity FG. A British Ophthalmological Surveillance Unit study on serious ocular injuries from fireworks in the UK. Eye. 2008;22(7):944-947.

10. Cole MD, Smerdon D. Perforating eye injuries caused by darts. Br J Ophthalmol. 1988;72(7):511-514.

11. Thornton J, Edwards R, Harrison RA, Elton P, Astbury N, Kelly SP. 'Smoke gets in your eyes': a research informed professional education and advocacy programme. J Public Health (Oxf). 2007;29(2): $142-146$.
Clinical Ophthalmology

\section{Publish your work in this journal}

Clinical Ophthalmology is an international, peer-reviewed journal covering all subspecialties within ophthalmology. Key topics include: Optometry; Visual science; Pharmacology and drug therapy in eye diseases; Basic Sciences; Primary and Secondary eye care; Patient Safety and Quality of Care Improvements. This journal is indexed on

Submit your manuscript here: http://www.dovepress.com/clinical-ophthalmology-journal

\section{Dovepress}

PubMed Central and CAS, and is the official journal of The Society of Clinical Ophthalmology (SCO). The manuscript management system is completely online and includes a very quick and fair peer-review system, which is all easy to use. Visit http://www.dovepress.com/ testimonials.php to read real quotes from published authors. 